\title{
The Glaciations in South America
}

\author{
Daniel G. Poiré, Lucía E. Gómez Peral, and María J. Arrouy
}

\section{Abstract}

Neoproterozoic successions in South America are recorded in many areas of Brazil, Paraguay, Bolivia, Uruguay and Argentina. Some of these units show glaciogenic formations like those represented in the Puga and Serra Azul formations in the Northern Paraguay Belt (Brazil) in agreement with their accumulation in a Snowball Earth context. However, in other cases, tillites or other glaciomarine deposits are absent, which may indicate a distant position (tropical) regarding the ice cap, as occurs in the Tandilia System (Argentina) related to a "Phantom glacial" context. In this contribution we show the comparison between direct and indirect evidence of glaciations in the Neoproterozoic successions of South America. The Puga and Serra Azul formations in the Paraguay Belt and Sierras Bayas Group in the Río de la Plata Craton have been chosen to describe the "Snowball Earth" and "Phantom glacial" models, respectively. By means of multiproxy analysis it is also possible to indicate changes in paleoclimate conditions in both cases. The presence of tillites is considered to be direct evidence of the extreme climatic conditions during deposition during a glaciation. Meanwhile, more subtle evidence such as regional unconformities related to drastic sea level changes, trends in $\delta^{13} \mathrm{C}$, events of phosphogenesis, constitute, among others, the tools to indicate the influence of Neoproterozoic global glaciations during the deposition of the sedimentary units.

\section{Keywords}

Paleoclimatic proxies - Neoproterozoic • Tillite records Phantom glacial deposits

D. G. Poiré $(\bowtie)$ L L. E. Gómez Peral · M. J. Arrouy Centro de Investigaciones Geológicas-CONICET-FCNyM (UNLP), Diag. $113 \mathrm{~N}^{\circ} 275$, esq. 64, 1900, La Plata, Argentina e-mail: dgpoire@yahoo.com.ar

\subsection{Introduction}

Neoproterozoic diamictite rocks such as tillites or glaciomarine deposits have been recorded as the product of regional glaciations around the world, in accordance with the Snowball Earth hypothesis (Hoffman et al. 1998). However, in some parts of the planet, contemporaneous non-glaciogenic sedimentary rocks have also been observed related to sedimentation in non-glacial environments but influenced by planetary glaciation, which was termed "Phantom glacial" (Cozzi et al. 2002; Poiré 2004) in a "slushball Earth" scenario. In the first model, the glacial mass covers the whole planet during glaciations, whereas in the slushball hypothesis the Earth was not completely frozen during periods of extreme glaciation (Hyde et al. 2000; Lewis et al. 2007; Micheel and Montenari 2008). Floating ice would have covered up to $60 \%$ of the ocean, but this left a lot of the ocean open, and littoral and low continental environments in the tropics without any ice cover. In this case, the total glacial mass was increasing while the sea level was falling, producing diamictites in the frozen areas around the world and falling sea-level deposits in tropical and equatorial regions. Phantom glacial deposits are those that are not glacial diamictites but show glacial sea level dropping sedimentation, such as deltas progradation, fluvial erosional unconformities and karstic surfaces on limestone shelves.

As synthesized by Sohl and Chandler (2007), of these two end-member climate conditions, the Snowball Earth glaciations have attracted most attention in recent years, in large part because of the discussion about the possible climatic influence on the evolution of macroscopic life. Previous iterations of the Snowball Earth hypothesis (Hoffman et al. 1998; Hoffman and Schrag 2002) have taken the geological evidence for widespread cold climates and extrapolated a vision of the world practically entombed in ice, with the oceans totally frozen. Proponents of the "hard" Snowball Earth have suggested that total or near-total sea-ice cover is 
necessary to explain both an interpreted rapid transition from the glacial to the non-glacial state, and unusual $\delta^{13} \mathrm{C}$ signatures, as low as $-5 \%$, in carbonate rocks ("cap carbonates") directly overlying the glacial deposits (Hoffman et al. 1998; Hoffman and Schrag 2002). Those in favor of a slightly less extreme scenario, the slushball Earth, point to sedimentary deposits (ice-rafted debris in deep marine settings) that can be used to argue in favor of more open ocean rather than less (e.g., McMechan 2000; Condon et al. 2002; Kellerhals and Matter 2003). Furthermore, some authors have suggested that icebergs have never reached equatorial positions, but the strong polar glaciations have led to falling sea levels with karstic surfaces in tropical and equatorial latitudes over carbonate platforms (Poiré 2004; Gómez Peral et al. 2014a, b, 2017).

The South American geological record shows both types of occurring given by successions with the presence of tillites ("Snowball Earth") and others without these diamictite deposits ("Phantom glacial"). The aim of this contribution is to make a comparison between evidence of the direct and indirect influence of glaciations in the Neoproterozoic successions of the Tandilia System and Northern Paraguay Belt (Fig. 19.1) as end-members of the climate conditions in South America. Thus the Puga Formation in Northern Paraguay Belt, Amazonia Craton in Brazil, and the Sierras Bayas Group in the Rio de la Plata Craton of Argentina have been chosen to describe both models. By means of multiproxy analysis it is also possible to indicate changes in paleoclimatic conditions in both cases.

The Paraguay Belt shows the occurrence of tillite deposits associated with glacial events and is in agreement with the Snowball Earth hypothesis.

In particular, the example of Phantom glacial is postulated on the basis of the development of regional karstic unconformities related to drastic sea level changes, trends in $\delta^{13} \mathrm{C}$ and phosphogenesis events, which among others constitute indirect evidence that can be used to indicate the influence of Neoproterozoic global glaciations during the deposition of the sedimentary units of the Tandilia System.

\subsection{Glacial Deposits in South America}

\subsubsection{Northern Paraguay Belt in the Amazonia Paleocontinent}

The Paraguay Belt is an extended region located on the southeastern edge of the Amazon Craton (Fig. 19.1), also defined as Amazonia Paleocontinent by Alvarenga et al. (2009). In the Northern Paraguay Belt, two indubitable Neoproterozoic tillite units have been recognized (Fig. 19.2): the Marinoan-aged Puga Formation and the

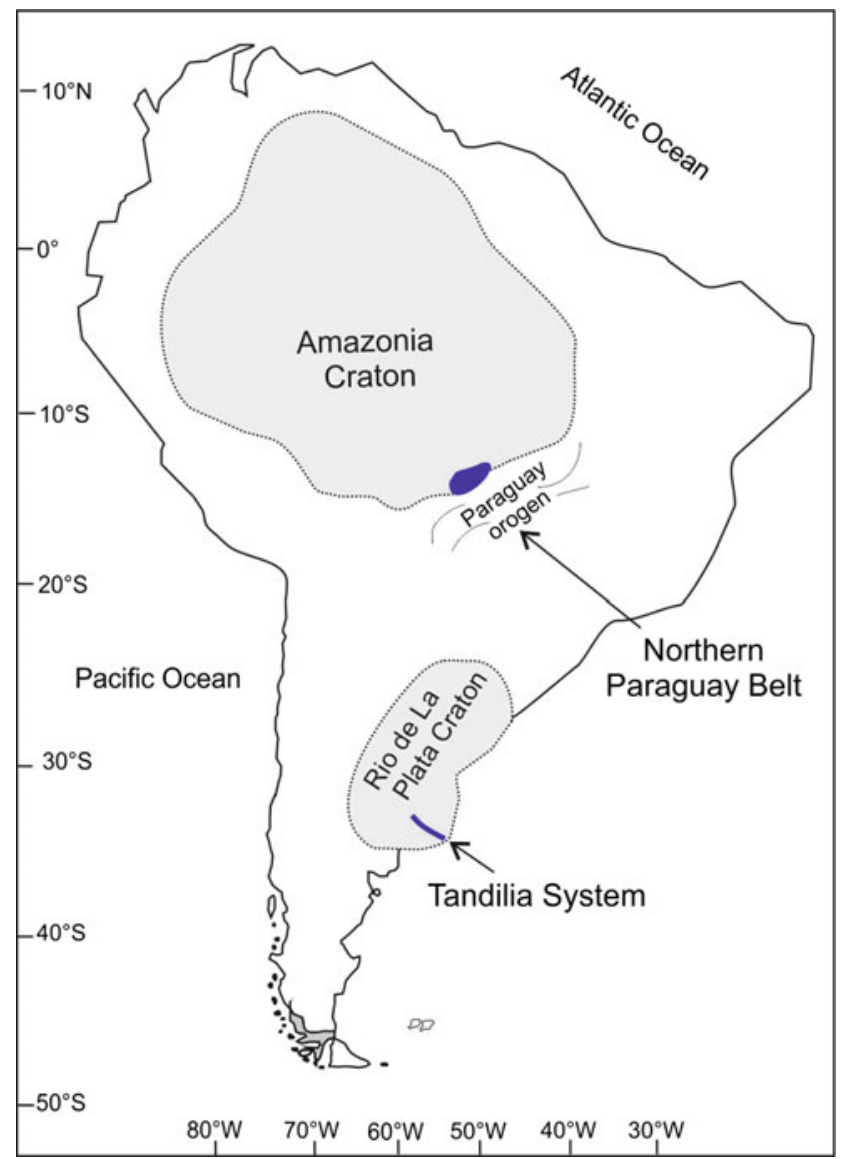

Fig. 19.1 General map of the Rio de la Plata craton and Amazonia craton of southern South America (modified from Rapela et al. 2016 and references therein)

Gaskiers-aged Serra Azul Formation (Alvarenga and Trompette 1992; Alvarenga et al. 2004, 2007, 2009).

Marinoan glacial deposits have also been identified in the Southern Paraguay Belt with carbonate rocks overlying the glaciogenic deposits. The Santa Cruz (Fig. 19.3a) and Puga formations in the Corumbá area have been correlated with this glacial event (635 Ma) based on cap-dolomite lithofacies, paleomagnetic data, and associated $\delta^{13} \mathrm{C}$ and ${ }^{87} \mathrm{Sr} /{ }^{86} \mathrm{Sr}$ isotope trends (Boggiani 1998; Trompette et al. 1998; Nogueira et al. 2003; Trindade et al. 2003; Alvarenga et al. 2004, 2009, 2011; Boggiani et al. 2004; Sial et al. 2016). However, tillites of the Puga Formation are better represented in the Northern Paraguay Belt (Figs. 19.2 and 19.3b). According to Alvarenga et al. (2011) and Sial et al. (2016), the Puga Formation was originally described from the Southern Paraguay Belt (Maciel 1959) but is not necessarily coeval with the homonymous unit in the Northern Paraguay Belt. Besides, the deposition of these Puga Formation terrigenous sediments in the south is probably associated with the development of a rift basin (Boggiani 1998; Gaucher et al. 2003). 


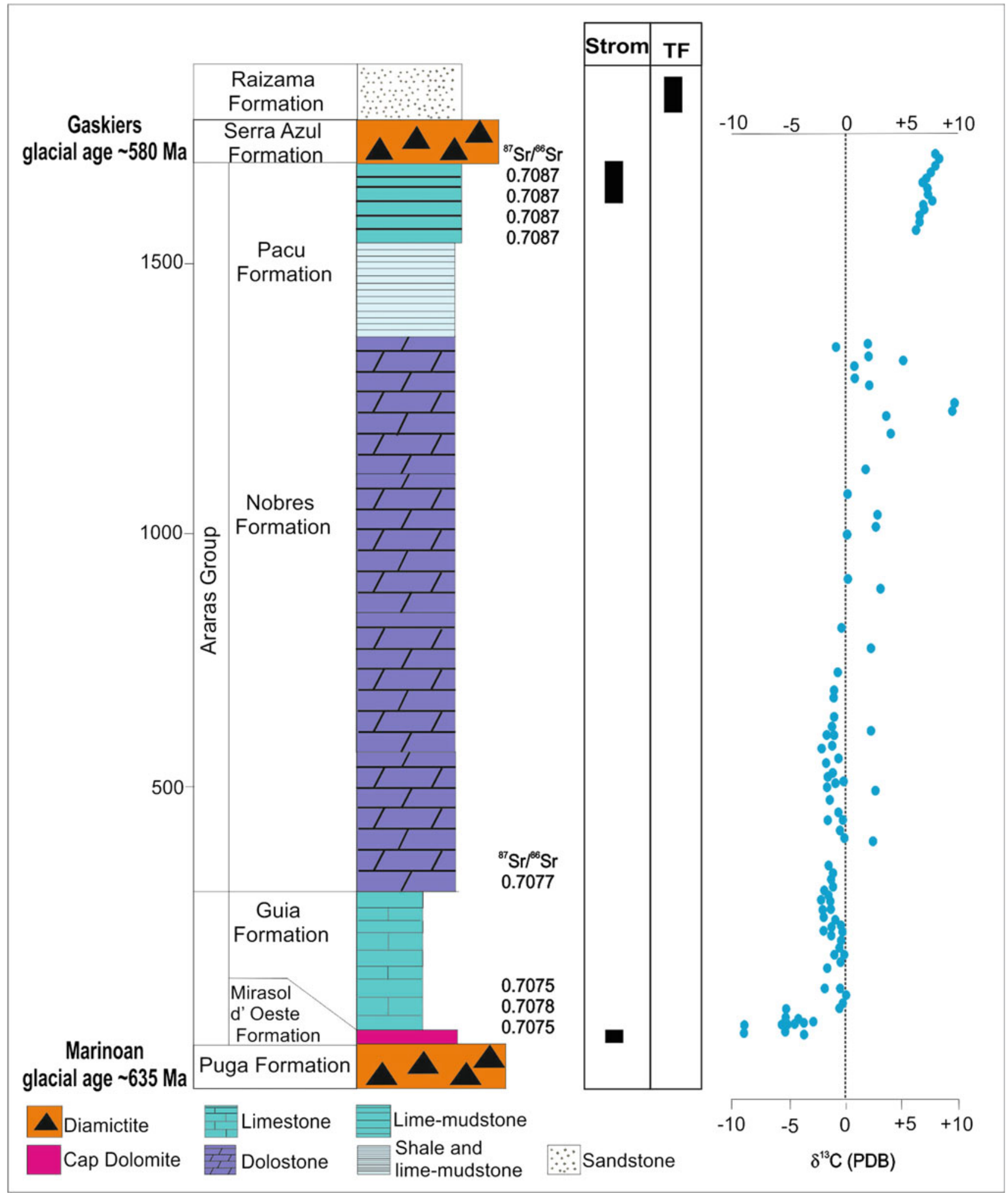

Fig. 19.2 Stratigraphic and bioestratigraphic section and variations in $\delta 13 \mathrm{C}$ and $87 \mathrm{Sr} / 86 \mathrm{Sr}$ for the Araras Group (modified from Sial et al. 2016) 

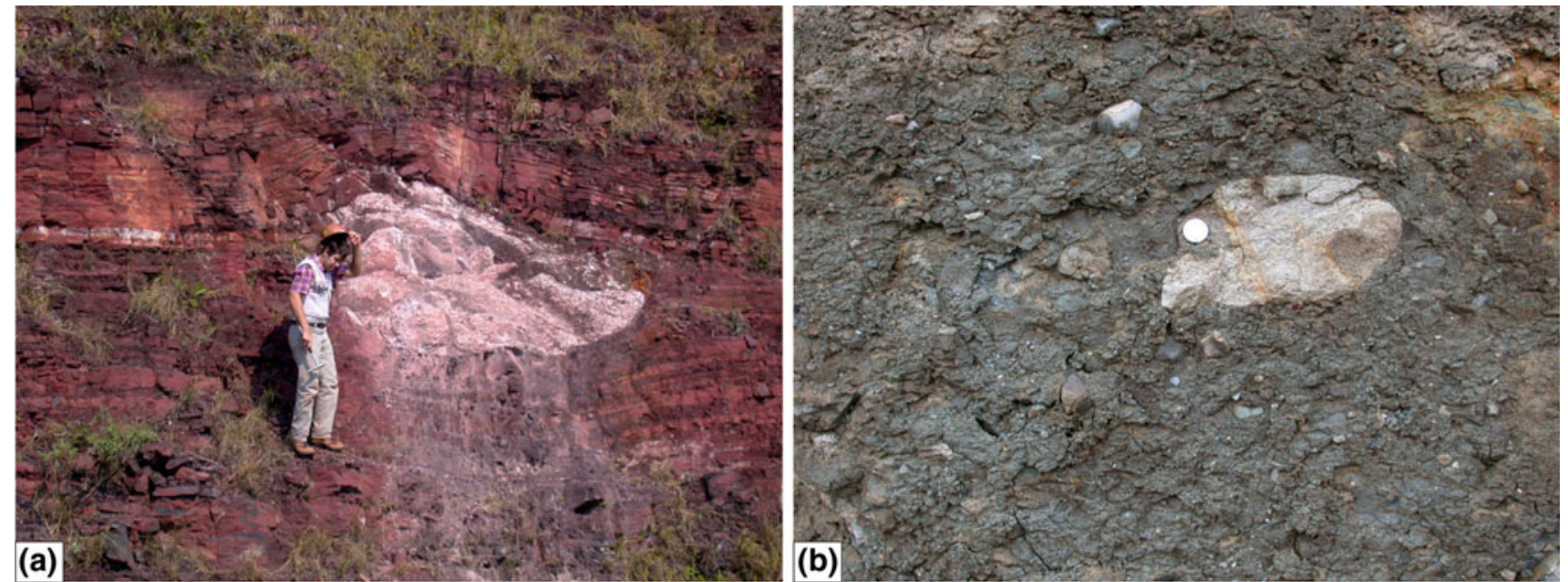

Fig. 19.3 Field photographs. a Granite megaclast dropstone in Santa Cruz Formation, Southern Paraguay Belt, Brazil. b Tillite of Puga Formation, Northern Paraguay Belt, Brazil

\subsubsection{Lithostratigraphy}

Lithostratigraphically, this region comprise a crystalline basement complex (gneisses, schists, granites, metaquartzites) overlain by a Neoproterozoic sedimentary succession that from bottom to top is composed of the Puga Formation, Araras Group (Mirassol d'Oeste, Guia, Nobres and Pacu formations) and Serra Azul Formation, all covered by the Ediacaran/Cambrian Razaima Formation (Fig. 19.2).

The Puga Formation (Maciel 1959) is the oldest depositional unit (100 m thick) and comprises purple, reddish, brownish or dark-greenish gray, pebbly tillite with striated clasts of granite and sandstone (Fig. 19.3b), also accompanied by conglomerates, sandstones, and shales. It has been interpreted as a glacial-marine deposit (Maciel 1959; Alvarenga and Trompette 1992). Based on detrital zircon ages (Babinski et al. 2013), paleomagnetic data (Trindade et al. 2003) and chemostratigraphy of the overlying limestones (Nogueira et al. 2003), this unit is considered Cryogenian in age.

The basal unit of the Araras Group is the Mirassol d' Oeste Formation (up to $30 \mathrm{~m}$ thick), which is composed of pinkish dolostones bearing stromatolites, tube-like structures, breccia, giant wave ripples, deformed microbialites dislocated by synsedimentary faults, red iron-oxide-rich mudstones in the top level (Nogueira et al. 2003; Alvarenga et al. 2004, 2008; Nogueira and Riccomini, 2006) and fan-like crystals interpreted as aragonite pseudomorphs (Alvarenga et al. 2008). The unit is interpreted as a moderately deep euphotic platform (Nogueira et al. 2003).

The middle one, the Guia Formation (up to $250 \mathrm{~m}$ thick), consists of dark-gray laminated limestones and shales, with slumps and other deformational sedimentary structures, interpreted as deposited in a deep platform environment (Nogueira et al. 2003).
The Nobres Formation (up to $1100 \mathrm{~m}$ thick) is composed mainly of light-gray grainstone, packstone dolostones, with some interlayered breccias. This unit was interpreted as a carbonate platform deposited under shallow-water sedimentation.

The uppermost unit of the Araras Group is the Pacu Formation ( $\sim 300 \mathrm{~m}$ thick), described as carbonate mudstones and stromatolitic limestones (Souza et al. 2012), in a coarsening upward succession, which was interpreted as deposited by a marine transgression followed by a regression with the development of a carbonate shallow marine platform during the Ediacaran (Souza 2015).

Above the Araras Group through an erosional surface, the Serra Azul Formation (up to $270 \mathrm{~m}$ thick) is recorded, composed of a very thick basal diamictite unit $(70 \mathrm{~m})$ of massive reddish diamictite with an abundant clay-silty matrix. Well-rounded to highly angular clasts (from millimeters to centimeters in diameter) are dispersed throughout the matrix, some of them reaching up to $30 \mathrm{~cm}$ in diameter. The composition of the clasts is sandstones, quartz, quartzites, arkoses, carbonates, cherts, basalts, rhyolites, diabases and weathered granitic rocks. Some faceted, polished and striated clasts have also been preserved in the diamictite (Alvarenga et al. 2007, 2009). These tillites are overlain by a succession of reddish laminated siltstone ( $25 \mathrm{~m}$ thick), which is overlaid by a rhythmite unit ( $175 \mathrm{~m}$ thick) interbeded with episodic sandstones (Alvarenga et al. 2009).

The Razaima Formation (up to $700 \mathrm{~m}$ thick) covers the Neoproterozoic sedimentary cover of the Northern Paraguay Belt, which consists of a siliciclastic succession. The lower part of this unit consists of whitish parallel-laminated and small-scale hummocky cross-stratified sandstone and pebbly sandstone, interbedded with parallel-laminated mudstone that grades upwards into swaley cross-stratified sandstone, 
forming a shallowing upward succession (Santos et al. 2017). The ichnogenera Skolithos, Arenicolites and Diplocraterion have been reported by Santos et al. (2017). According to these authors, (1) these trace fossils are therefore consistent with sedimentologic data which indicates a wave-dominated nearshore environment, and (2) the ichnofauna are suggesting an early Cambrian age or younger for the Raizama Formation in contrast to the previously held view of an Ediacaran age for this unit.

\subsubsection{Glacial Deposits of Puga Formation}

The Puga Formation tillites were correlated with the Marinoan glaciation related to Araras Group cap-carbonate lithofacies, paleomagnetic data, and associated $\delta^{13} \mathrm{C}$ and ${ }^{87} \mathrm{Sr} /{ }^{86} \mathrm{Sr}$ isotope trends (Nogueira et al. 2003; Pinho et al. 2003; Trindade et al. 2003; Alvarenga et al. 2004). Over the diamictites of the Puga Formation, the cap dolostone of the Mirassol d'Oeste Formation is succeeded by transgressive, deep-platform deposits of dark-gray laminated limemudstone and shales of the Guia Formation, reaching up to $250 \mathrm{~m}$ thick in the middle shelf domain (Alvarenga et al. 2004, 2008, 2011; Nogueira et al. 2007; Riccomini et al. 2007).

$\mathrm{Ca}$ isotopic compositions of post-glacial carbonate successions in central Brazil (Mirassol d'Oeste-Cáceres and Tangará) have been reported by Silva-Tamayo et al. (2010a, b). These authors indicate that the $\mathrm{Ca}$-isotope secular variation trend is similar to those of Marinoan post-glacial carbonate successions in Namibia, suggesting that the perturbation of the marine Ca cycle was, perhaps, global. Carbon isotope data for rocks of the Guia Formation revealed predominantly negative $\delta^{13} \mathrm{C}$ values, from -3.5 to $0.1 \%$, and $\delta^{18} \mathrm{O}$ values from $-13.5 \%$ to $-6.3 \%$ (Nogueira et al. 2003, 2007; Alvarenga et al. 2004, 2008; Figueiredo 2006). ${ }^{87} \mathrm{Sr} /{ }^{86} \mathrm{Sr}$ ratios for limestones with a higher $\mathrm{Sr}$ content $(>750 \mathrm{ppm})$ and low $\mathrm{Mn} / \mathrm{Sr}$ ratios $(<0.2)$ range from 0.7076 to 0.7078 (Alvarenga et al. 2008, 2011).

\subsubsection{Glacial Deposits of Serra Azul Formation}

Dropstones and striated clasts provide evidence of a glacial setting for the Serra Azul diamictite (Fig. 19.2). This unit is composed of massive diamictite with an abundant clay-silty matrix (70 $\mathrm{m}$ thick), followed by a thick succession of laminated siltstone $(200 \mathrm{~m})$. This unit is not overlaid by a cap carbonate, as was reported for the Puga Formation. The Serra Azul Formation was described as discontinuous outcrops of diamictites and siltstones above post-Marinoan carbonates of the Araras Group (Fig. 19.2), and it represents a record of the Gaskiers glaciation (Alvarenga et al. 2007) with an age of c. $580 \mathrm{Ma}$ (Knoll et al. 2004).

\subsection{Phantom Glacial Deposits in South America}

\subsubsection{Tandilia System in the Río de La Plata Craton}

The Neoproterozoic sedimentary cover of the Tandilia System in the Sierras Bayas- Olavarría area comprises a $\sim 455 \mathrm{~m}$-thick succession, which overlays a crystalline basement. The Sierras Bayas Group (Villa Mónica, Colombo, Cerro Largo, Olavarría and Loma Negra formations) and La Providencia Group (Avellaneda, Alicia and Cerro Negro formations) are compound this sedimentary cover (Fig. 19.4a), which are composed of different carbonate and siliciclastic units separated by regional unconformities (Poiré 1987; Iñiguez et al. 1989; Poiré and Spalletti 2005; Poiré and Gaucher 2007, 2009; Arrouy et al. 2015).

\subsubsection{Lithostratigraphy}

\section{Crystalline Basement}

The Buenos Aires Complex (Marchese and Di Paola 1975) is composed of granitoids, migmatites, mylonites, amphibolites and basic dykes (Cingolani and Dalla Salda 2000), yielding U-Pb SHRIMP ages of between 2234 and $2065 \mathrm{Ma}$ (Cingolani et al. 2002; Hartmann et al. 2002a, b; Cingolani 2011) and Sm-Nd model ages averaging around $2620 \pm$ 80 Ma (Pankhurst et al. 2003).

\section{Sierras Bayas Group}

In the Olavarría-Barker area (Fig. 19.4a) the overlying Neoproterozoic lithostratigraphic units are grouped into five depositional intervals (Fig. 19.4b) (Poiré et al. 2003; Poiré and Spalletti 2005; Poiré and Gaucher 2009). Detrital zircon $\mathrm{U}-\mathrm{Pb}$ ages indicate a Paleoproterozoic to Mesoproterozoic source of clastic material in the Neoproterozoic succession (Rapela et al. 2007, 2011; Gaucher et al. 2008; Cingolani 2011). Gaucher et al. (2008) and Cingolani (2011) observe an obvious change in detrital provenance from the basal to the upper formations (see also Zimmerman et al. 2011, who provide geochemical evidence for a change in provenance).

The basal unit, the Villa Mónica Formation (52-70 m thick), exhibits two sedimentary facies associations: quartz-arenite and arkosic sandstone at the base, and dolostone including shallow marine stromatolites and shale-marls at the top (Poiré 1993; Gaucher and Poiré 2009a).

The erosional surface above the Villa Mónica Formation, the Piedra Amarilla Surface, is followed by breccias and diamictites of the Colombo Formation (Poiré and Gaucher 
Fig. 19.4 a Location map of Argentina in South America and study area in the Tandilia System, Buenos Aires Province, Argentina (modified from Iñiguez 1989). b Schematic representation of the lithostratigraphic, biostratigraphic and quimiostratigraphic

successions of Sierras Bayas and La Providencia Groups (Poiré and Gaucher 2009; Arrouy et al.

2015; Gómez Peral et al. 2017)
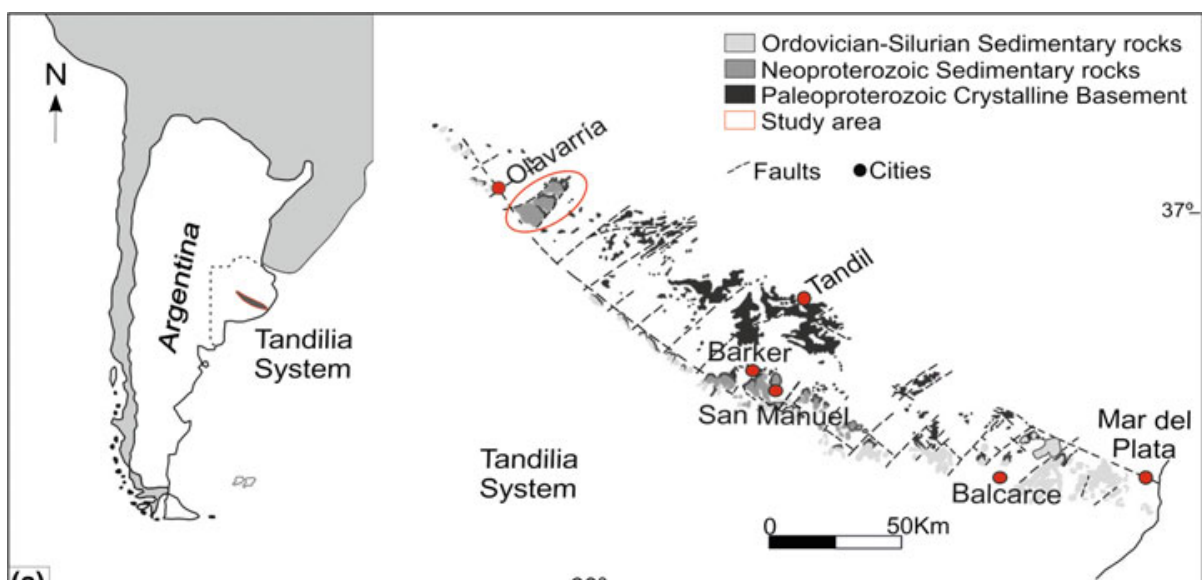

(a) $60^{\circ}$

(b)

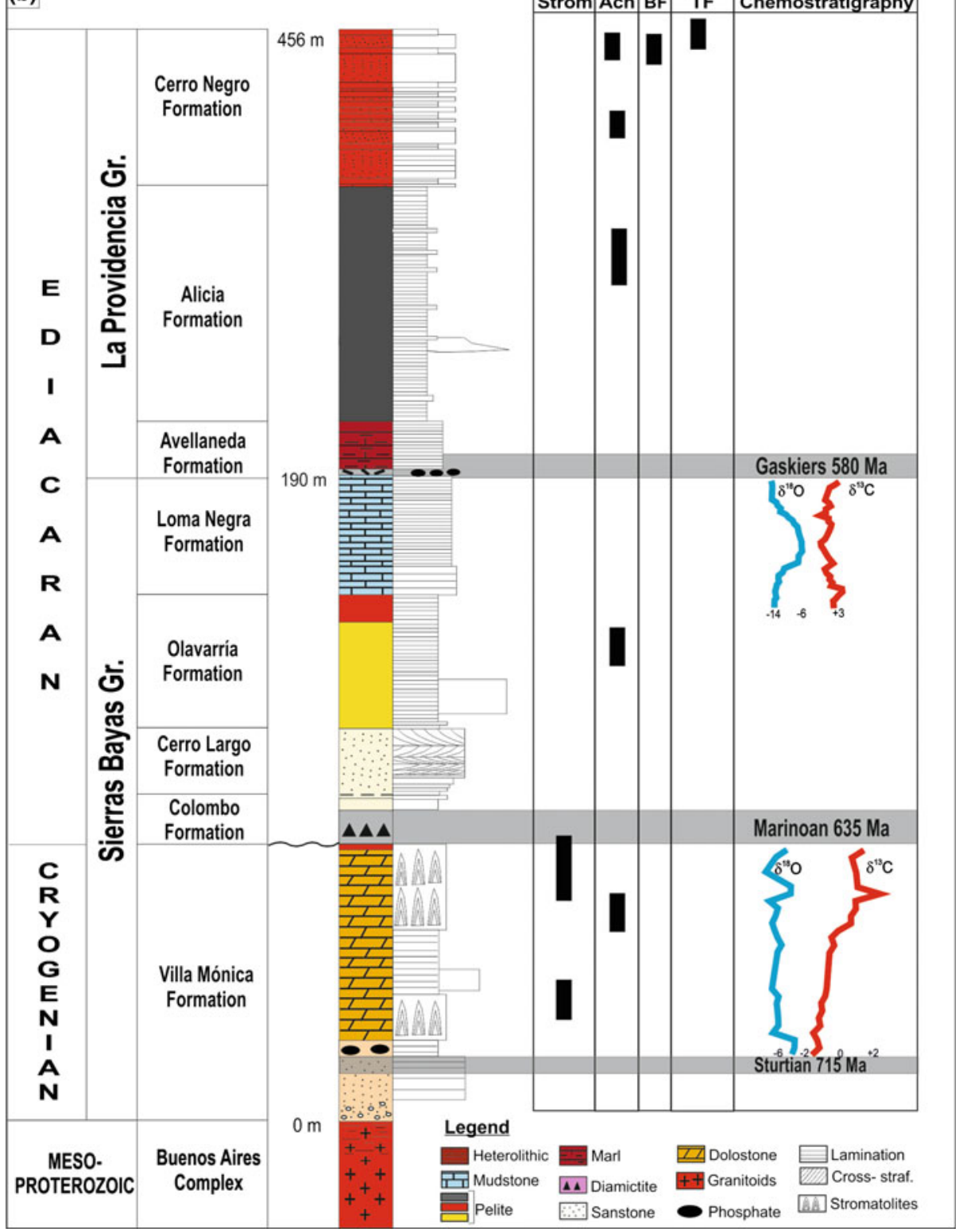


2009; Gómez-Peral et al. 2011). The diamictites (Gaucher and Poiré 2009b) contain blocks up to $3 \mathrm{~m}$ in diameter (i.e., sandstone, shale, dolostone and chert breccia), synsedimentary deformation structures, and a sandy-muddy matrix (Gómez-Peral et al. 2011). Rapalini et al. (2013) assigned a tentative age for the Piedra Amarilla Surface of $590 \mathrm{Ma}$ on the basis of paleomagnetic data. Above the diamictite, finely laminated glauconitic shales and fine-grained sandstones appear in the basal part of the Cerro Largo Formation. The upper part of this unit consists of cross-bedded quartz sandstones with sigmoidal, herringbone and hummocky cross-stratification (Gómez-Peral et al. 2011). This succession represents a shallowing-upward succession, ranging from subtidal nearshore to tidal-flat deposits (Poiré 1987; Poiré and Gaucher 2009).

The overlying Olavarría Formation is approximately $35 \mathrm{~m}$ thick and includes a transitional basal contact represented by quartzite to mudstone heterolithic facies. Mudstone and heterolithic facies contain 8-20 cm concretionary iron-rich beds (Gómez-Peral et al. 2011).

The youngest depositional unit of the Sierras Bayas Group is the Loma Negra Formation (Figs. 19.2b), which is represented by $40 \mathrm{~m}$ exclusively composed of micritic limestones originating from suspension fall-out in open marine platform environment. The age of the Loma Negra Formation was debated. It was suggested first as $\sim 540-550 \mathrm{Ma}$, based on the presence of Cloudina (Gaucher et al. 2005), but it could be older ( 580-590 Ma) considering $\delta^{13} \mathrm{C}$ and ${ }^{87} \mathrm{Sr} /{ }^{86} \mathrm{Sr}$ combined trends (Gómez Peral et al. 2007). Moreover, in the overlying Cerro Negro Formation, Arrouy et al. (2016) described typical morphs of Aspidella (related to the 560550 Ma White Sea assemblage; Wagooner 2003).

\section{La Providencia Group}

The Sierras Bayas Group is overlain discordantly by $\mathrm{La}$ Providencia Group. The basal Avellaneda Formation is the filling of a channelized paleosurface (Barker surface, Fig. 19.4b) composed on common chert breccias (Barrio et al. 1991) with phosphate concretions first recognized by Leanza and Hugo (1987). The Avellaneda Formation (up to $25 \mathrm{~m}$ thick) is composed mostly of red to purple laminated and massive marls at the base, which grade vertically into red massive mudstones (Fig. 19.2b). This formation was interpreted as deposited under supratidal conditions in a tidal-flat depositional environment, probably in well-oxygenated conditions (Arrouy 2015; Arrouy et al. 2015).

The Alicia Formation (up to $150 \mathrm{~m}$ thick) conformably overlies the previous one and is composed of dark fissile mudstones and massive gray siltstones, as well as gray heterolithics with lenticular and wavy bedding (Fig. 19.2b). This facies succession was interpreted to represent low-energy subtidal settings, likely with suboxic to anoxic bottom conditions (Arrouy 2015; Arrouy et al. 2015).

The Cerro Negro Formation $(\sim 100 \mathrm{~m})$ unconformably rests on the previous, and represents an abrupt change to red heterolithics with wavy and flaser bedding, together with cross-laminated and massive, fine- to medium-grained sandstones (Fig. 19.4b). Mudcracks, scour marks and flutes are common in this succession, which was interpreted to represent subtidal to intertidal settings, probably with well-oxygenated substrates. The top of this succession has been removed by erosion in both the subsurface and outcrops (Arrouy 2015; Arrouy et al. 2015).

\subsubsection{Geobiology}

The Neproterozoic sedimentary cover of the Tandilia System is very rich in signs of primitive life. These include stromatolites, Ediacaran Biota, trace fossils, microbial induced sedimentary structures (MISS) and acritarchs.

Stromatolites of the Villa Monica Formation of the Sierras Bayas Group include Colonnella fm., Conophyton fm., Conophyton ressoti, Cryptozoon fm., Gongylina fm., Gymnosolen fm., Inzeria fm., Jacutophyton fm., Jurusania cf. nisvensis, Katavia fm., Kotuikania fm., Kussiella fm., Minjaria fm., Parmites fm., Parmites cf. concrescens and Stratifera fm (Poiré 1987, 1989, 2002; Poiré and Spalletti 2005). Megascale studies show that the lower and upper parts of this dolostone unit are composed of 0.5-1.4 m-thick domal biostromes and 0.1-0.5 m-thick interbiostromal green shales. A few bioherms are present at the top of this unit. In contrast, in the middle part the stromatolites are completely absent. Domal biostromes are very conspicuous and they reflect the strong influence of paleocurrents in their morphogenesis. The direction of elongation was perpendicular to the shoreline. Two types of elongated bioconstruction are distinguished: symmetrical and asymmetrical. The latter suggests their acute end-points out to sea. The measured paleocurrents suggest a north-south local shoreline direction with open sea towards the east (Poiré 1987, 1989).

Very abundant and diverse discoidal structures in fine-grained micaceous sandstones, associated with abundant MISS, in the Cerro Negro Formation of the La Providencia Group, were assigned to the genera Aspidella sp. as the oldest record of Ediacaran macrobiota in South America (Arrouy et al. 2016). In this unit, Skolithos isp., Helminthopsis isp. and bilobate trace fossils are also reported (Poiré and Spalletti 2005; Arrouy et al. 2016).

In terms of microfossils, the Sierras Bayas Group contains acritarchs assigned to Chuaria circularis, Leiosphaeridia minutissima, L. tenuissima and Synsphaeridium sp. In addition, Leiosphaeridiajacutica, L. tenuissima and Synsphaeridium sp. from Sierras Bayas and La Providencia 
groups were also recognized in the shales (Gaucher et al. 2005; Gaucher and Poiré 2009a).

\subsubsection{Synglacial Sea Level Falls}

Two major stratigraphic discontinuities are recorded in the Sierras Bayas Group, including the lower surface at the contact between the Villa Mónica and Cerro Largo formations, "Piedra Amarilla Surface" (Fig. 19.5a), and the upper surface on top of the Loma Negra Formation, "Barker Surface" (Fig. 19.5b). The latter may have been expressed worldwide and related to glacial eustacy insofar as it has been correlated with other Neoproterozoic omission surfaces in Uruguay, Brazil, South Africa and Namibia (Poiré et al. 2007; Praekelt et al. 2008; Germs and Gaucher 2012). Both of the Sierras Bayas unconformities are associated with the development of karst on carbonate lithologies filled with diamictite, chert and phosphate concretions, and intraformational breccia (Fig. 19.5). On the other hand, the transitional or planar contacts between the Cerro Largo and Olavarría formations, and the Olavarría and Loma Negra formations, reflect variations in paloenvironmental conditions, recognized primarily by pronounced lithological changes (Fig. 19.5b).

The Piedra Amarilla Surface was defined as a karstic surface (Gómez Peral et al. 2011), which is located at the contact between the Villa Mónica and Colombo formations (Fig. 19.5a) dividing the Sierras Bayas Group in two sections with very different depositional and diagenetic stories. Some iron-rich levels related to the basal Colombo Formation were placed by paleomagnetic studies in $\sim 595 \mathrm{Ma}$ (Rapallini et al. 2013). On the other hand, some iron concentrations were related to hydrothermal activity (Gómez Peral et al. 2012), as well as in the Barker area (Martínez et al. 2010) related to hydrothermal activity between 620 and $590 \mathrm{Ma}$ based on K/Ar ages (Martínez et al. 2013).

Siliceous cementation and replacement were assumed for subaerial exposure when the $\mathrm{pH}$ dropped. This subaerial exposure is associated with an important sea-level fall whose relation to glaciation can be assumed, probably as a response to the Marinoan global event.

The Barker surface (Fig. 19.5b) is on top of the Sierras Bayas Group and has been correlated with other Neoproterozoic surfaces in SW Gondwana in Uruguay, Brazil, South Africa and Namibia, and related tentatively to the Gaskiers glaciation (Poiré et al. 2007; Gaucher and Poiré 2009b; Gaucher et al. 2009). This surface is associated with a drastic regional sea-level fall that exposed the Loma Negra shelf carbonates (Barrio et al. 1991; Gómez Peral 2008).

Telodiagenetic processes were defined in detail by Gómez Peral (2008), where besides the intense silicification also hematite constitutes a frequent type of cementation related to meteoric fluids during kastification. This is strong evidence of subaerial exposure.

\subsubsection{Paleoclimate-Controlled Chemostratigraphy}

Trends in $\delta^{13} \mathrm{C}$ curves from the dolostones of Villa Mónica Formation showed consistent values from -2 to $2.6 \%$ (Gómez Peral et al. 2017) and $\delta^{18} \mathrm{O}$ values vary from -2 to $6 \%$. Dolostones immediately above a subtle diamictite level show the lowest $\delta^{13} \mathrm{C}$ value. ${ }^{87} \mathrm{Sr} /{ }^{86} \mathrm{Sr}$ values are $\sim 0.7069$. The clear positive trend of $\delta^{13} \mathrm{C}$ was considered to suggest this unit as a cap dolostone (Fig. 19.4b; Gómez Peral et al. 2017). In addition, low Sr content in was associated with precipitation influenced by fresh water (Brand and Veizer 1981; Veizer 1983), $\mathrm{Mn} / \mathrm{Sr}$ ratios $<6$ and $\mathrm{Rb} / \mathrm{Sr}<0.002$ (Gómez Peral et al. 2017).

The Loma Negra Formation, composed almost exclusively of micritic limestones, shows constant positive values of $\delta^{13} \mathrm{C}$ ranging between 2.2 and $4.5 \%$ (Fig. 19.4b), $\delta^{18} \mathrm{O}$ values varying from -8 to $-14 \%$, and ${ }^{87} \mathrm{Sr} /{ }^{86} \mathrm{Sr}$ values from 0.7070 to 0.7082 . The later uplift of the succession in relation to the implantation of the karstic surface on top of the sequence was related to a regional sea level fall, later linked to the Gaskiers glacial event ( $\sim 580 \mathrm{Ma})$, but no negative $\delta^{13} \mathrm{C}$ anomalies have been mentioned to date. The Sr content is $\sim 400 \mathrm{ppm}$ on average and $\mathrm{Mn} / \mathrm{Sr}<1.4$ (Gómez Peral et al. 2007) are in agreement with carbonate platforms developed in warmer conditions. In addition, the paleogeographic position of the Río de La Plata Craton suggested by Merdith et al. (2017) between 600 and 560 Ma coincides with a tropical latitude.

\subsubsection{Post-glacial Events of Phosphogenesis}

Two phosphogenic events were recorded in the Neoproterozoic successions of the Tandilia System. The older one occurring just below the cap-dolostone (Upper Villa Mónica Formation) was considered to be Cryogenian based on stromatolite assemblages, carbon isotope trends and strontium isotope abundances of $<0.7071$ (Gómez Peral et al. 2014a, b). This level (Fig. 19.6a) occurs in the contact between the lower and upper sections of the Villa Mónica Formation, where phosphate concretions are interbedded with iron-rich shales (Gómez Peral et al. 2014a, b).

The later event of phosphogenesis was over the karstic Barker surface and was Ediacaran in age (Gómez Peral et al. $2014 a$, b). This phosphate horizon is at the base of the Avellaneda Formation and is composed of phosphate and chert concretions in either a laminated shale or mudstone matrix (Fig. 19.6b; Gómez Peral et al. 2014a, b). This level was first recognized by Leanza and Hugo (1987), who interpreted it as the filling of a channelized paleosurface resulting from sea-level regression. 

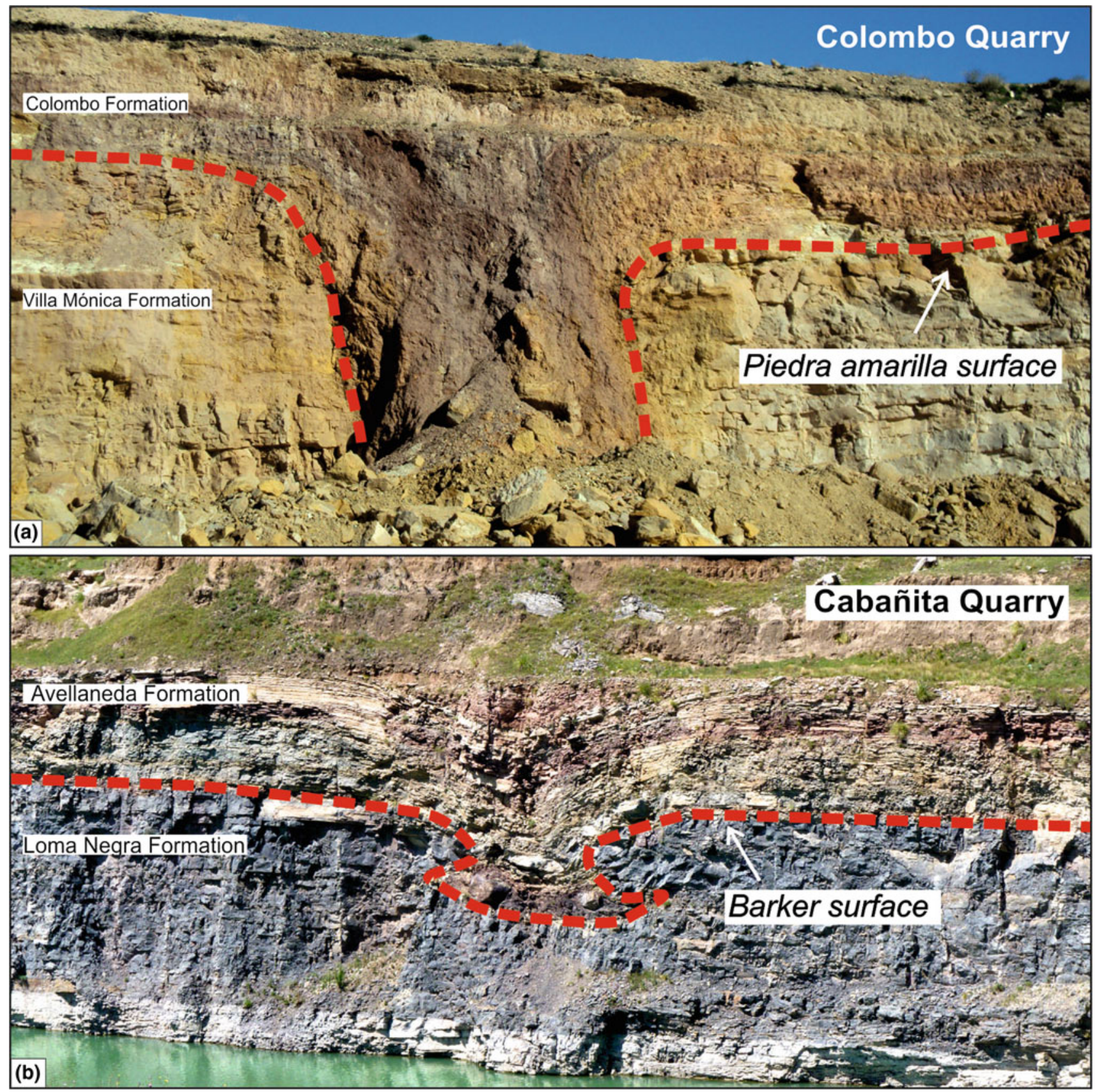

Fig. 19.5 Field photographs. a Piedra Amarilla karstic surface in the Colombo Quarry, Olavarría, Argentina. b Barker karstic surface in the Polcecal Quarry (Olavarría)

These two levels have been suggested as the result of events of generalized phosphogenesis related to relative sea-level fall and exposure in response to glacial eustacy. The reported oxic seawater conditions where phosphate was concentrated in the Neoproterozoic Tandilia System were markedly different for both levels. The Villa Mónica phosphates was related to stratified ocean under reducer conditions, while the Avellaneda level reveals well oxygenated conditions regarding Ce anomalies (Fig. 19.6; Gómez Peral et al. 2014a, b). 
Fig. 19.6 Schematic representation of the two phosphogenesis events in the Tandilia System.

a Paleoenvironment of the Villa Mónica phosphate level with a stratified basin (positive $\mathrm{Ce}$ anomaly). b Paleoenvironment scheme of the Avellaneda phosphate level (ex Cerro Negro Formation) with well-mixed ocean and normal circulation of oxygen (negative $\mathrm{Ce}$ anomaly) (modified from Gómez Peral et al. 2014a, b)
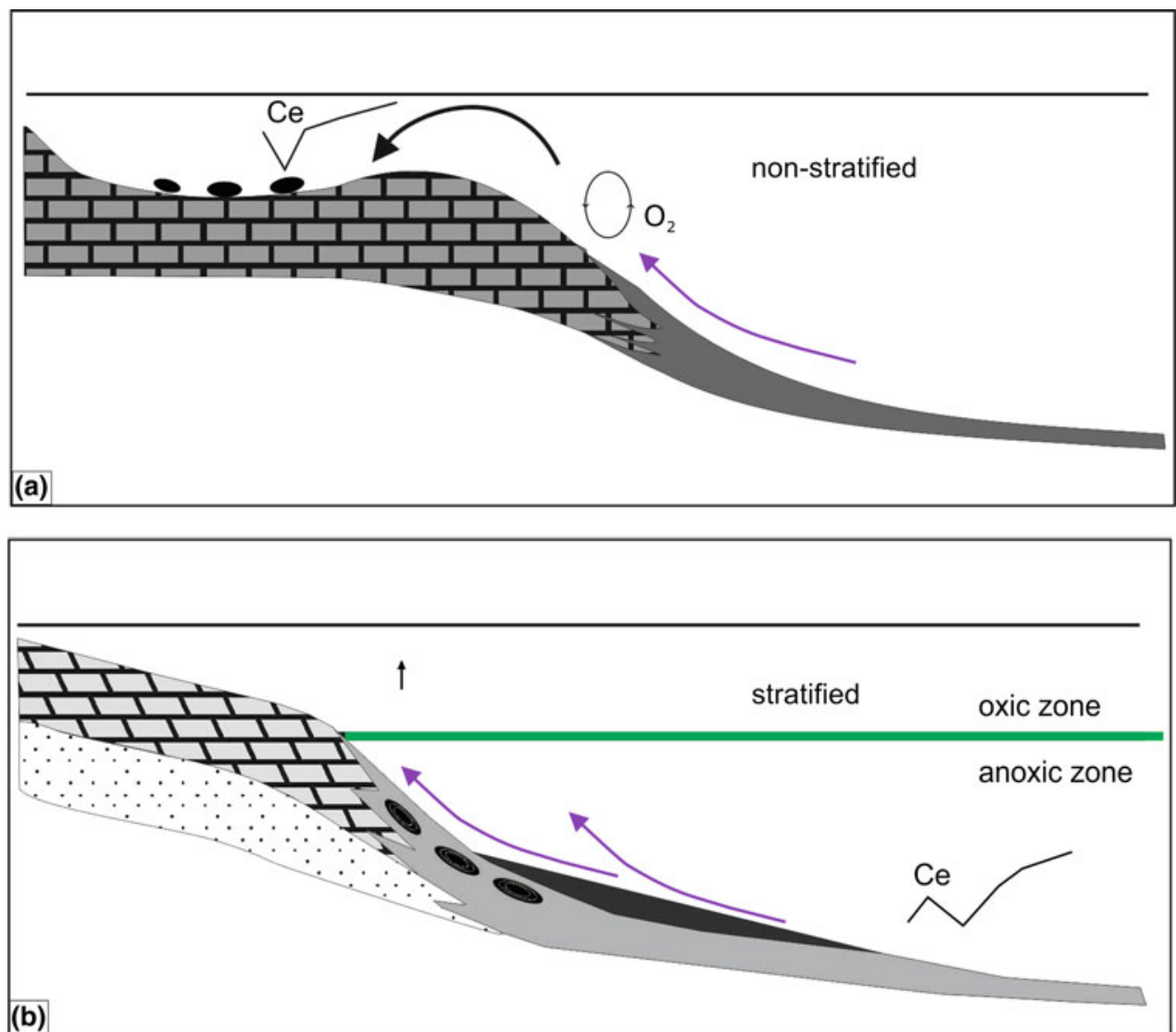

\subsection{Other Examples of Tillites, Phantom Glacial Deposits and Indeterminate Diamictites in South America}

Besides the above mentioned glacial deposits of the Puga and Serra Azul formations in the Northern Paraguay Belt, and the Santa Cruz Formation in the Southern Paraguay Belt, other Neoproterozoic tillites were referred to in South America (Fig. 19.7). In the Nico Perez Terrane, Uruguay, the diamictites of the Playa Hermosa Formation show the presence of glacial deposits as was suggested by Pazos et al. (2003). Meanwhile the contemporaneous Las Ventanas Formation in the same terrane seems to be associated with rift deposits below the Arroyo del Soldado Group (Blanco and Gaucher 2005, 2014) or above the Mina Verdún Group (Poiré et al. 2005; Poiré 2014) (Fig. 19.7).

Other regions of Brazil show different types of diamictite. For instance, the origin of the Puga Formation conglomerates in its type locality seems to be related to a tectonic event, as previously mentioned (Boggiani 1998; Gaucher et al. 2003) (Fig. 19.7). The Tamengo Formation of the Corumbá Group (Boggiani 1998; Gaucher et al. 2003; Boggiani et al. 2010) bearing Cloudina and Corumbella fossils associated with volcanic ash levels at the top, which yielded a U-Pb SHRIMP age of $543 \pm 2$ Ma (Babinski et al. 2008), is another good example of the Phantom glacial model. Over the Tamengo Formation limestones, the shales of the Guaicurus Formation have been correlated with the regional karstic "Barker surface" (Poiré et al. 2007; Poiré and Gaucher 2009b). The Itapucumí Group in Paraguay (Fig. 19.7) also reflects a Phantom glacial model because there are no tillites in the siliciclastic units below the limestones and the upper limestones are perfectly correlated with the Tamengo Formation (Warren 2011; Warren et al. 2011, 2012). The Tucavaca Group in Bolivia near Corumbá suggests the same environmental conditions during its sedimentation (Fig. 19.7).

The Bambuí and Una groups (São Francisco Supergroup) in Brazil are formed by carbonate and siliciclastic successions, with some diamictites overlaid by limestones. However, the glacial origin of these diamictites is still under discussion (Kaufman et al. 2009; Warren et al. 2014; Sial et al. 2016 and references therein).

In Argentina the Colombo Formation in the Río de la Plata Craton constitutes a dubious diamictite deposit considering its origin, but this needs further detailed analysis to understand the depositional processes during its sedimentation (Fig. 19.7). In the Sierras Pampeanas terrane, some limestones and marls are interpreted as Phantom glacial 
Fig. 19.7 Compilation of glacial, phantom glacial deposits and undefined, dubious or tectonic conglomerates in South America

\begin{tabular}{|c|c|c|}
\hline $\begin{array}{l}\text { Glacial } \\
\text { (tillites) }\end{array}$ & $\begin{array}{c}\text { Phantom glacial } \\
\text { deposits }\end{array}$ & $\begin{array}{l}\text { Undefined, dubious or } \\
\text { tectonic diamictites }\end{array}$ \\
\hline $\begin{array}{l}\text { Santa Cruz Formation } \\
\text { Southern Paraguay Belt }\end{array}$ & $\begin{array}{l}\text { Villa Mónica Formation } \\
\text { Rìo de la Plata Craton }\end{array}$ & $\begin{array}{c}\text { Puga Formation } \\
\text { Southern Paraguay Belt }\end{array}$ \\
\hline $\begin{array}{l}\text { Puga Formation } \\
\text { Northern Paraguay Belt }\end{array}$ & $\begin{array}{c}\text { Loma Negra/Avellaneda } \\
\text { Formations } \\
\text { Río de la Plata Craton }\end{array}$ & $\begin{array}{l}\text { Las Ventanas Formation } \\
\text { Nico Pérez Terrane }\end{array}$ \\
\hline $\begin{array}{l}\text { Serra Azul Formation } \\
\text { Northern Paraguay Belt }\end{array}$ & $\begin{array}{c}\text { Sierra de Ancasti } \\
\text { metacarbonates } \\
\text { Sierras Pampeanas Terrane }\end{array}$ & $\begin{array}{l}\text { Colombo Formation } \\
\text { Río de la Plata Craton }\end{array}$ \\
\hline \multirow[t]{4}{*}{$\begin{array}{l}\text { Playa Hermosa Formation } \\
\text { Nico Pérez Terrane }\end{array}$} & $\begin{array}{l}\text { Difunta Correa marbles } \\
\text { Sierras Pampeanas Terrane }\end{array}$ & $\begin{array}{c}\text { Bambui Group } \\
\text { San Francisco Craton }\end{array}$ \\
\hline & $\begin{array}{l}\text { Tamengo Formation } \\
\text { Souther Paraguay Belt }\end{array}$ & $\begin{array}{c}\text { Una Group } \\
\text { San Francisco Craton }\end{array}$ \\
\hline & $\begin{array}{l}\text { Itapucumi Group } \\
\text { Paraguay }\end{array}$ & \\
\hline & $\begin{array}{c}\text { Tucavaca Group } \\
\text { Bolivia }\end{array}$ & \\
\hline
\end{tabular}

deposits because there are no diamictites below the carbonate levels ("pseudo-cap carbonate"). The metacarbonates of La Calera Quarry in the Ancasti Range (Murra et al. 2011, 2016) is one example of Phantom glacial deposits, with ${ }^{87} \mathrm{Sr} /{ }^{86} \mathrm{Sr}$ ratios of $0.70831-0.70860$ and $0.70747-0.70781$, and values of $\mathrm{C}$ and $\mathrm{O}$ in three samples of $\delta^{13} \mathrm{C}_{\mathrm{PDB}} \sim 8.36$ to $9.05 \%$, $\delta^{18} \mathrm{O}_{\mathrm{SMOW}} \sim 19.37$ to $22.23 \%$ (Murra et al. 2011). According to Murra et al., these carbonates are post-Marinoan in age. A similar consideration was proposed by Galindo et al. (2004) for the Difunta Correa marbles in Córdoba Province in the same Sierras Pampeanas terrane (Fig. 19.7).

\subsection{Discussion and Conclusions}

In this chapter we focus on a comparison between Snowball Earth and Phantom glacial scenarios represented in different successions of South America. Regarding different evidence of glaciations in the Neoproterozoic successions, we choose the Puga and Serra Azul formations in the Paraguay Belt, Amazonia Craton, and the Sierras Bayas Group in the Río de la Plata Craton in order to compare the two models, also related to their different paleolatitudinal position.

The Snowball Earth hypothesis (Hoffman et al. 1998) proposes that Neoproterozoic tillite deposits are recorded as the product of regional glaciations around the world. However, in the Río de La Plata Craton, contemporaneous successions are related to sedimentation in non-glacial environments or Phantom glacial (Cozzi et al. 2002; Poiré 2004).

The Snowball Earth context is well represented by some units of undoubted glaciogenic origin such as the Puga and Serra Azul formations in Northern Paraguay Belt (Brazil) that were related to Marinoan $(\sim 635 \mathrm{Ma})$ and Gaskiers ( $580 \mathrm{Ma})$ glacial events.

On the other hand, the Phantom glacial context is characterized by the successions of the Tandilia System (Argentina) related to a tropical paleogeographic position for this time interval and even older (Cryogenian), in which indirect evidence of those glaciations is also postulated.

Although no tillites were recorded in the Río de La Plata Craton (Argentina), synglacial sea level falls represented by two main karstic discordances over carbonate platforms, the Piedra Amarilla and Barker Surfaces, are considered to be a response of seawater cooling in a distant position with respect to the ice cover.

Conversely, cap-carbonates are defined as deposited over glacial diamictites (Mirasol d'Oeste Fm, Paraguay Belt, Brazil), but a "cap-dolostone" was also referred to (Upper Villa Mónica Formation) by the isotopic trends, Sr content, direct dolomicrite precipitation and tubestone stromatolitic 
morphologies related to deglacial meltwater environmental conditions (Gómez Peral et al. 2017). A Cryogenian phosphogenic event reported in the Neoproterozoic successions of the Tandilia System, associated with a very discrete level of mudstones with dropstones (Fig. 19.6, Lower Villa Mónica Formation; Gómez Peral et al. 2014a, b) of age $\sim 710 \mathrm{Ma}$, is postulated as another indirect piece of evidence of the influence of the Sturtian glaciation.

The Barker surface (Fig. 19.5b) on top of the carbonates of the Loma Negra Formation was correlated with others in SW-Gondwana in Uruguay, Brazil, South Africa and Namibia, and related tentatively to the Gaskiers glaciation (Poiré et al. 2007; Gaucher and Poiré 2009b). These micritic limestones show constant positive values of $\delta^{13} \mathrm{C}$ ranging between 2.2 and $4.5 \%$ and ${ }^{87} \mathrm{Sr} /{ }^{86} \mathrm{Sr}$ from 0.7070 to 0.7082 (Gómez Peral et al. 2007). Later uplift drive in subaerial exposure and meteoric diagenesis in relation to the implantation of the karstic surface on top of the sequence that was also linked to the Gaskiers glacial event ( $\sim 580 \mathrm{Ma}$ ). However, no negative $\delta^{13} \mathrm{C}$ anomalies have been mentioned to date. The age of this karst in association with the Ediacaran phosphogenesis event (Fig. 19.6b; Gómez Peral et al. 2014a, b) is supported by the presence of Aspidella in the overlying succession (Arrouy et al. 2016).

The two phosphate levels were suggested as being the result of events of generalized phosphogenesis related to relative sea-level fall and exposure in response to glacial eustacy.

Finally, we consider that multiproxy analysis allows the identification of changes in paleoclimate conditions in both cases. In one case, the presence of tillites is considered irrefutable evidence of glaciation particularly when a cap-carbonate is involved, but in the other model the development of regional karstic unconformities related to drastic sea level falls and associated phosphogenesis and trends in $\delta^{13} \mathrm{C}$ constitute indirect evidence of the influence of a Phantom glacial during their deposition, under a less extreme climate context.

\section{References}

Alvarenga CJS et al (2004) C-O-Sr isotopic stratigraphy of cap carbonates overlying Marinoan-age glacial diamictites in the Paraguay, Brazil. Precambrian Res 131:1-21

Alvarenga CJS et al (2007) Glacial diamictites of Serra Azul Formation (Ediacaran, Paraguay belt): Evidence of the Gaskiers glacial event in Brazil. J South Am Earth Sci 23:236-241

Alvarenga CJS et al (2009) The amazonian palaeocontinent. In: Gaucher $\mathrm{C}$ et al (eds) Neoproterozoic-Cambrian Tectonics, global change and evolution: a focus on Southwestern Gondwana. Developments in Precambrian Geology, vol 16. Elsevier, pp 15-28

de Alvarenga CJS, Trompette R (1992) Glacial influenced turbidite sedimentation in the uppermost Proterozoic and Lower Cambrian of the Paraguay belt (Mato Grosso, Brazil). Palaeogeogr Palaeoclimatol Palaeoecol 92:85-105
Alvarenga CJS, Boggiani PC, Babinski M, Dardenne MA, Figueiredo MF, Dantas EL, Uhlein A, Santos RV, Sial AN, Trompette R (2011) Glacially infuenced sedimentation of the Puga Formation, Cuiabá Group and Jacadigo Group, and associates carbonates of the Araras and Corumbá groups, Paraguay Belt, Brazil. In: Arnaud E, Halverson GP, Shields-Zhou G (eds) The Geologiacal Record of Neoproterozoic Glaciations, vol 36. Geological Society, London, Memoirs, pp 487-497

Alvarenga CJS, Dardenne MA, Santos RV, Brod ER, Gioia SMCL, Sial AN, Dantas EL, Ferreira VP (2008) Isotope stratigraphy of Neoproterozoic cap carbonates in the Araras Group, Brazil. Gondwana Res 13:469-479

Arrouy MJ (2015) Sedimentología y estratigrafía de los depósitos ediacareano-paleozoicos suprayacentes a las calizas del precámbrico del Sistema de Tandilia, provincia de Buenos Aires, Argentina. Tesis doctoral, Facultad de Ciencias Naturales y Museo, Universidad Nacional de La Plata, pp 285 (online SEDICI-UNLP)

Arrouy MJ et al (2015) Sedimentología y estratigrafía del grupo La Providencia (Nom. Nov.): Cubierta Neoproterozoica, Sistema de Tandilia, Argentina. Lat Am J Sedimentol Basin Anal 22(2):1-38

Arrouy MJ et al (2016) Ediacaran discs from South America: probable soft-bodied macrofossils unlock the paleogeography of the Clymene Ocean. Sci Rep 6(30590):1-10. https://doi.org/10.1038/srep30590

Babinski $M$ et al (2013) Detrital zircon ages and geochronological constraints on the Neoproterozoic Pugadiamictites and associated BIFs in the southern Paraguay Belt, Brazil. Gondwana Res 23:988-997

Babinski M, Boggiani PC, Fanning CM, Fairchild TR, Simon CM, Sial AN (2008) On isotope geology U-Pb SHRIMP geochronology and isotope chemostratigraphy $(\mathrm{C}, \mathrm{O}, \mathrm{Sr})$ of the Tamengo Formation, Southern Paraguay Belt, Brazil. In: Linares E, Cabaleri NG, do Campo MD, Ducós EI, Panarello HO (eds) Proceedings of VI South American Symposium. CDROM, Buenos Aires

Barrio C et al (1991) El contacto entre la Formación Loma Negra (Grupo Sierras Bayas) y la Formación Cerro Negro, un ejemplo de paleokarst, Olavarría, provincia de Buenos Aires. Revista de la Asociación Geológica Argentina 46:69-76

Blanco G, Gaucher C (2005) Estratigrafa, paleontologia y edad de la Formacion Las Ventanas (Neoproterozoico, Uruguay). Latin American J Sedimentol Basin Anal 12(2):109-124

Blanco G, Gaucher C (2014) Formación Las Ventanas. In: Bossi J, Gaucher C (eds) Geología del Uruguay. Tomo 1. Predevónico. Polo, Montevideo, pp 299-312

Boggiani PC (1998) Analise estratigráfica da Bacia Corumba (Neoproterozoíco), Mato Grosso do Sul. Unpublished $\mathrm{PhD}$ thesis, University of Sao Paulo, Brazil, pp 181

Boggiani PC et al (2004) New level of diamictites in the Corumbá Group (Ediacaran), Paraguay belt, South America. Symposium on Neoproterozoic-Early Paleozoic Events in SW-Gondwana, 1, Extended Abstracts, IGCP Project 478, Second Meeting, Brazil, pp $10-12$

Boggiani PC, Gaucher C, Sial AN, Babinski M, Simon CM, Riccomini C, Ferreira VP, Fairchild TR (2010) Chemostratigraphy of the Tamengo Formation (Corumbá Group, Brazil): a contribution to the calibration of the Ediacaran carbon isotope curve. Precambrian Res 182:382-401

Brand U, Veizer J (1981) Chemical diagenesis of multicomponent carbonate system: Stable isotopes. J Sediment Petrol 51:987-997

Cingolani CA, Dalla Salda L (2000) Buenos Aires cratonic region. In: Cordani U et al (eds) Tectonic evolution of South America. Proceedings 31st International Geological Congress, Río de Janeiro, pp 139-146

Cingolani CA et al (2002) U-Pb SHRIMP dating of zircons from the Buenos Aires complex of the Tandilia belt, Río de La Plata cratón, Argentina. 15 Congreso Geológico Argentino (El Calafate, Santa Cruz). Actas 1:149-154 
Cingolani C (2011) The Tandilia System of Argentina as a southern extension of the Río de la Plata craton: An overview. Int J Earth Sci 100:221-242

Condon DJ et al (2002) Neoproterozoic glacial-rainout intervals: observations and implications. Geology 30:35-38

Cozzi A et al (2002) Last gasp of "snowball Earth"? 2 A "phantom" glacial from the Late Neoroterozoic Shuram Formation of Oman. 16 International Sedimentological Congress, Abstracts, pp 68-69

Figueiredo MF (2006) Quimioestratigrafia das rochas ediacaranas no extremo norte da Faixa Paraguai, Mato Grosso. Unpublished dissertação de Mestrado, Instituto de Geociências, Universidade de São Paulo, Brazil

Galindo C et al (2004) Sr, Cand O isotope geochemistry and stratigraphy of Precambrian and lower Paleozoic carbonate sequences from the Western Sierras Pampeanas of Argentina: Tectonic implications. Precambr Res 131:55-71

Gaucher C, Finney SC, Poiré DG, Valencia VA, Grove M, Blanco G, Pamoukaghlián K, Gómez Peral L (2008) Detrital zircon ages of Neoproterozoic sedimentary successions in Uruguay and Argentina: insights into the geological evolution of the Río de la Plata Craton. Precambrian Res 167:150-170

Gaucher C, Poiré DG (2009a) Biostratigraphy. NeoproterozoicCambrian evolution of the Río de la Plata Palaeocontinent. In: Gaucher C et al (eds) Neoproterozoic-Cambrian Tectonics, Global change and evolution: a focus on Southwestern Gondwana. Developments in Precambrian Geology, vol 16. Elsevier, pp 103-114

Gaucher C, Poiré DG (2009b) Palaeoclimatic events. NeoproterozoicCambrian evolution of the Río de la Plata Palaeocontinent. In: Gaucher C et al (eds) Neoproterozoic-Cambrian tectonics, Global change and evolution: a focus on Southwestern Gondwana. Developments in Precambrian Geology, vol 16. Elsevier, pp 123-130

Gaucher C et al (2003) Integrated correlation of Vendian to Cambrian Arroyo del Soldado and Corumbá Groups (Uruguay and Brazil): Palaeogeographic, palaeoclimatic and palaeobiologic implications. Precambr Res 120:241-278

Gaucher C et al (2005) Litoestratigrafía, bioestratigrafía y correlaciones de las sucesiones sedimentarias del Neoproterozoico-Cámbrico del Cratón del Río de La Plata (Uruguay y Argentina). Lat Am J Sedimentol Basin Anal 12(2):145-160

Gaucher C et al (2009) Chemostratigraphy. Neoproterozoic-Cambrian evolution of the Río de la Plata Palaeocontinent. In: Gaucher $\mathrm{C}$ et al. (eds) Neoproterozoic-Cambrian tectonics, global change and evolution: a focus on Southwestern Gondwana. Developments in Precambrian Geology, vol 16. Elsevier, pp 115-122

Germs GJB, Gaucher C (2012) Nature and extent of a late Ediacaran (ca. $547 \mathrm{Ma}$ ) glacigenic erosion surface in southern Africa. South African J Geol 115:91-102

Gómez-Peral LE (2008) Petrología y diagénesis de las unidades sedimentarias precámbricas de Olavarría, Provincia de Buenos Aires. Tesis doctoral, Facultad de Ciencias Naturales y Museo, Universidad Nacional de La Plata Tomo I: pp 327 y tomo II: pp 292 (online SEDICI-UNLP)

Gómez-Peral LE, Poiré DG, Strauss H, Zimmermann U (2007) Chemostratigraphy and diagenetic constraints on Neoproterozoic carbonate successions from the Sierras Bayas Group, Tandilia System, Argentina. Chem Geol 237, 127-146

Gómez-Peral LE et al (2011) Petrología y evolución diagenética de las facies silicoclásticas del Grupo Sierras Bayas, Sistema de Tandilia, Argentina. Lat Am J Sedimentol Basin Anal 18(1):3-41

Gómez-Peral LE et al (2012) Isotope stratigraphic evidence for a Neoproterozoic cap-carbonate in Sierras Bayas Group, Tandilia System, Argentina. VIII Simposio Sudamericano de Geología isotópica, 5 al 7 de julio de 2012, Medellín, Colombia, Actas CD
Gómez-Peral LE et al (2014a) Paleoenvironmental implications of two phosphogenic events in Neoproterozoic sedimentary successions of the Tandilia System, Argentina. Precambr Res 252: 88-106

Gómez-Peral LE et al (2014b) Origen y diagénesis del karst del Tope de la Formación Villa Mónica, Sistema de Tandilia, Argentina. Actas XIV Reunión Argentina de Sedimentología, Madryn, 1-5 Septiembre de 2014

Gómez-Peral LE et al (2017) Paleoclimatic and paleoenvironmental evolution of the Early Neoproterozoic basal dolomitic platform, Río de La Plata Craton, Argentina: Insights from the $\delta^{13} \mathrm{C}$ chemostratigraphy. Sed Geol 353:139-157

Hartmann LA et al (2002a) Zircon and titanite U-Pb SHRIMP geochronology of Neoproterozoic felsic magmatism on the eastern border of the Rio de la Plata Craton, Uruguay. J South Am Earth Sci 15:229-236

Hartmann LA et al (2002b) Two Paleoproterozoic orogenies in the evolution of the Tandilia Belt, Buenos Aires, as evidenced by zircon U-Pb SHRIMP geochronology. Int Geol Rev 44:528-543

Hoffman PF, Schrag DP (2002) The snowball Earth hypothesis: Testing the limits of global change. Terra Nova 14:129-155

Hoffman PF et al (1998) A Neoproterozoic snowball Earth. Science 281:1342-1346

Hyde WT et al (2000) Neoproterozoic snowball Earth simulations with a coupled climate/ice-sheet model. Nature 405:425-429

Iñiguez AM et al (1989) Cuenca precámbrica-paleozoica inferior de Tandilia, Provincia de Buenos Aires. In: Chebli G, Spalletti LA (eds) Cuencas Sedimentarias Argentinas. Serie Correlación Geológica 6: $245-263$

Kaufman AJ et al (2009) Neoproterozoic to Cambrian Palaeoclimatic events in Southwestern Gondwana. In Gaucher C et al (eds) Neoproterozoic-Cambrian tectonics, global change and evolution: a focus on Southwestern Gondwana. Developments in Precambrian Geology, vol 16. Elsevier, Amsterdam, pp 369-388

Kellerhals P, Matter A (2003) Facies analysis of a glaciomarine sequence, the Neoproterozoic Mirbat Sandstone Formation, Sultanate of Oman. Eclogae Geologicae Helvetiae 96:49270

Knoll AH et al (2004) A new period for the geologic time scale. Science 305:621-622

Knoll AH et al (2006) The Ediacaran period: a new addition to the geologic time scale. Lethaia 39:13-30

Leanza HA, y Hugo CA (1987) Descubrimiento de fosforitas sedimentarias en el Proterozoico superior de Tandilia, Buenos Aires, Argentina. Revista Asociación Geológica Argentina 42(3-4): 417-428

Lewis JP et al (2007) Snowball versus slushball Earth: dynamic versus nondynamic sea ice? J Geophys Res112(C11)

Maciel P (1959) Tilito Cambriano (?) no Estado de Mato Grosso. Boletim da Sociedade Brasileira de Geologia 81(1):31-39

McMechan ME (2000) Neoproterozoic glaciogenic slope deposits, Rocky Mountains, northeast British Columbia. Bull Can Pet Geol 48:2462261

Marchese HG, Di Paola E (1975) Miogeosinclinal Tandil. Revista de la Asociación Geológica Argentina 30(2):161-179

Martínez JC et al (2010) A hydrothermal clay mineral assemblage at the Late Proterozoic unconformity in the Buenos Aires Complex- La Tinta Formation, Barker area, Tandilia Ranges (Argentina). Clays Minerals 45:209-224

Martínez JC et al (2013) Late-Neoproterozoic hidrotermal fluid activity in the Tandilia Belt, Agentina. Revista de la Asociación Geológica Argentina 70(3):410-426

Merdith AS et al (2017) A full-plate global reconstruction of the Neoproterozoic. Gondwana Res. https://doi.org/10.1016/j.gr.2017. 04 
Micheels A, Montenari M (2008) A snowball Earth versus a slushball Earth: Results from Neoproterozoic climate modeling sensitivity experiments. Geosphere 4(2):401-410

Murra JA et al (2011) Sr, C and O isotope composition of marbles from the Sierra de Ancasti, Eastern Sierras Pampeanas, Argentina: age and constraints for the Neoproterozoic-Lower Paleozoic evolution of the proto-Gondwana margin. Geological Acta 9:79-92

Murra JA et al (2016) Isotope (Sr, C) and U-Pb SHRIMP zircon geochronology of marble-bearing sedimentary series in the Eastern Sierras Pampeanas, Argentina. Constraining the SW Gondwana margin in Ediacaran to early Cambrian times. Precambr Res 181:602-617

Nogueira ACR, Riccomini C (2006) O Grupo Araras (Neoproterozoico) na parte norte da Faixa Paraguai e sul do Craton Amazônico, Brazil. Revista Brasileira de Geociências 36(4):623-640

Nogueira ACR et al (2003) Soft-sediment deformation at the base of the Neoproterozoic Puga cap carbonate (Southwestern Amazon Craton, Brazil): confirmation of rapid icehouse to greenhouse transition in Snowball Earth. Geology 31:613-616

Nogueira ACR et al (2007) Carbon and strontium isotope fluctuations and paleoceanographic changes in the late Neoproterozoic Araras carbonate platform, Southern Amazon Craton, Brazil. Chem Geol 237:168-190

Pankhurst RJ et al (2003) Antiquity of the Río de la Plata craton in Tandilia, southern Buenos Aires province, Argentina. J S Am Earth Sci 16:5-13

Pazos PJ et al (2003) The Record of the Varanger Glaciation at Río de la Plata Craton. Vendian-Cambrian of Uruguay. Gondwana Research 6(1):65-78

Pinho FEC et al (2003) Contribution to the Neoproterozoic C and O isotopic record: Carbonate rocks from the Paraguay Belt, Mato Grosso, Brazil, vol 1. In: IV South American symposium on isotope geology, Salvador, Brasil, Short Papers, pp 386-389

Poiré DG (1987) Mineralogía y sedimentología de la Formación Sierras Bayas en el Núcleo Septentrional de las sierras homónimas, partido de Olavarría, provincia de Buenos Aires. Unpublished PhD thesis 494, Facultad de Ciencias Naturales y Museo, Universidad Nacional de La Plata pp 27

Poiré DG (2004) Sedimentary history of the Neoproterozoic of Olavarría, Tandilia System, Argentina: new evidence from their sedimentary sequences and unconformities: a "snowball Earth" or a "phantom" glacial? $1^{\circ}$ Symposium on Neoproterozoic-Early Paleozoic Events in SW-Gondwana.Extended Abstract: 46-48, San Pablo, Brasil.

Poiré DG (1989) Stromatolites of the Sierras Bayas Group, Upper Proterozoic of Olavarría, Sierras Septentrionales, Argentina. Stromatolite Newsl 11:58-61

Poiré DG (1993) Estratigrafía del Precámbrico sedimentario de Olavaría, Sierras Bayas, Provincia de Buenos Aires, Argentina. XII Congreso Geológico Argentino y II Congreso de Exploración de Hidrocarburos Actas II:1-11

Poiré DG (2002) The Precambrian/lower Paleozoic sedimentary cover of Tandilia System, Argentina. In: Gaucher C, Poiré DG (eds) II International Colloquium Vendian-Cambrian of W. Gondwana, field trip guide. Facultad de Ciencias-UNESCO, Montevideo, pp 55-66

Poiré DG (2014) Grupo Mina Verdún, In Bossi, J., Gaucher, C. (eds) Geología del Uruguay. Tomo 1: Predevónico, Montevideo, Polo, pp 233-251

Poiré DG, Gaucher C (2007) Lithostratigraphy and correlations of two Neoproterozoic basins from the Río de la Plata Craton, SW-Gondwana. In: III Symposium on neoproterozoic-early palaeozoic events in Southwestern Gondwana, Programme and Short Papers, Stellenbosch, pp 23-27
Poiré DG, Gaucher C (2009) Lithostratigraphy. NeoproterozoicCambrian evolution of the Río de la Plata Palaeocontinent. In: Gaucher $\mathrm{C}$ et al (eds) Neoproterozoic-cambrian tectonics, global change and evolution: a focus on Southwestern Gondwana. Developments in Precambrian Geology, vol 16, pp 87-101

Poiré, D.G., Spalletti, L.A. (2005) La cubierta sedimentaria precámbrica/paleozoica inferior del Sistema de Tandilia. In De Barrio, R.E. et al. (eds) Geología y Recursos Minerales de la provincia de Buenos Aires. Relatorio del XVI Congreso Geológico Argentino, 51-68. La Plata

Poiré DG et al (2003) The Cambrian-Ordovician siliciclastic platform of the Balcarce Formation (Tandilia System, Argentina): Facies, trace fossils, palaeoenvironments and sequence stratigraphy. Geologica Acta 1:41260

Poiré DG et al (2005) Estratigrafía del Grupo Mina Verdún, Precámbrico de Minas, Uruguay. Lat Am J Sedimentol Basin Anal 12(2):125-143

Poiré DG et al (2007) La superficie 'Barker' y su importancia regional, Neoproterozoico del Cratón del Río de La Plata. VI Jornadas Geológicas y Geofísicas Bonaerenses. Actas 36. Mar del Plata, Argentina

Praekelt HE, Germs GJB, Kennedy JH (2008) A distinct unconformity in the Cango Caves Group of the Neoproterozoic to early Paleozoic Saldania Belt in South Africa: its regional significance. South African J Geol 111:357-368

Rapalini AE et al (2013) The La Tinta pole revisited: Paleomagnetism of the Neoproterozoic Sierras Bayas Group (Argentina) and its implications for Gondwana and Rodinia. Precambr Res 224:51-70

Rapela CW et al (2007) The Río de la Plata Craton and the assembly of SW Gondwana. Earth-Sci Rev 83:49-82

Rapela CW et al (2011) The Rio de la Plata craton and the adjoining Pan-African/brasiliano terranes: their origins and incorporation into south-west Gondwana. Gondwana Res 20:673-690

Rapela CW, Verdecchia SO, Casquet C, Pankhurst RJ, Baldo EG, Galindo C, Murra JA, Dahlquist JA, Fanning CM (2016) Identifying Laurentian and SW Gondwana sources in the Neoproterozoic to Early Paleozoic metasedimentary rocks of the Sierras Pampeanas: Paleogeographic and tectonic implications. Gondwana Res 32:193-212

Riccomini C et al (2007) Carbon and oxygen isotope geochemistry of Ediacaran outer platform carbonates, Paraguay Belt, central Brazil. An Acad Bras Ciênc 79(3):519-527

Santos HP et al (2017) Ichnologic evidence of a Cambrian age in the southern Amazon Craton: Implications for the onset of the Western Gondwana history. J S Am Earth Sci 76:482-488

Sial AN et al (2016) Correlations of some Neoproterozoic carbonate-dominated successions in South America based on high-resolution chemostratigraphy. Braz J Geology 46(3):439-488

Silva-Tamayo JC et al (2010a) Global Ca isotope variations in c. $0.7 \mathrm{Ga}$ old post-glacial carbonate successions. In: Karhu J et al (eds) Precambrian Isotope Stratigraphy, vol 182. Special issue. Precambrian Research, pp 373-381

Silva-Tamayo JC et al (2010) Global Ca isotope variations in Post-Sturtian carbonate successions. Terra Nova 22:188-194

Sohl LE, Chandler MA (2007) Reconstructing Neoproterozoic palaeoclimates using a combined data/modelling approach. In: Williams M et al (eds) Deep-time perspectives on climate change: marrying the signal from computer models and biological proxies. The Micropalaeontological Society, Special Publications. The Geological Society, London, pp 61-80

Souza JO et al (2012) Projeto Planalto da Serra. Estado de Mato Grosso, Programa Geologia do Brasil, CPRM, Goiânia, p 105

Souza SCR (2015) Detalhamento Estratigráfico das Unidades superiores do Neoproterozóico da Faixa Paraguai. Unpublished MSc thesis, Instituto de Geociências, Universidade de Brasília, Brazil 
Trindade RIF et al (2003) Low-latitude and multiple geomagnetic reversals in the Neoproterozoic Puga cap carbonate of Amazonia. Terra Nova 15:441-446

Trompette R et al (1998) Geological evolution of the Neoproterozoic Corumbágraben system (Brazil). Depositional context of the stratified $\mathrm{Fe}$ and $\mathrm{Mn}$ ores of the Jacadigo Group. J S Am Earth Sci 11:587-597

Veizer J (1983) Chemical Diagenesis of carbonates: theory and application of trace element technique. Stable Isotopes in Sedimentary Geology. S.E.P.M. Short Course 10(3-1): 3-100

Waggoner B (2003) The Ediacaran biotas in space and time. Integr Comp Biol 43:104-113

Warren LV (2011) Tectônica e sedimentação do Grupo Itapucumi (Neoproterozóico, Paraguai Setentrional. Unpublished doctoral thesis, Institute of Geosciences, University of São Paulo, São Paulo, pp 215

Warren LV et al (2011) Corumbella and in situ Cloudina in association with thrombolites in the Ediacaran Itapucumi Group, Paraguay. Terra Nova 23:382-389

Warren LV et al (2012) The dawn of animal skeletogenesis: ultrastructural analysis of the Ediacaran metazoan Corumbella werneri. Geology 40:691-694

Warren LV et al (2014) The puzzle assembled: Ediacaran guide fossil Cloudina reveals an old proto-Gondwana seaway. Geology 42:391-394

Zimmermann U et al (2011) Neoproterozoic to Lower Palaezoic successions of Tandilia system in Argentina: implication for the palaeotectonic framework of southwest Gondwana. Int J Earth Sci 100:489-510 